\title{
RADON LEVELS IN PORTUGUESE THERMAL SPAS ${ }^{*}$
}

\author{
A.S. Silva1,2, M.L. Dinis ${ }^{1,2 * *}$, A.J.S.C. Pereira3 ${ }^{3}$ A. Fiúza ${ }^{2}$ \\ ${ }^{1}$ CERENA, FEUP/UPorto - Centre for Natural Resources and the Environment \\ ${ }^{2}$ University of Porto, Faculty of Engineering, PROA/LABIOMEP - Research Laboratory on Prevention of Occupational \\ and Environmental Risks, Porto, Portugal \\ 3University of Coimbra, CEMUC, Department of Earth Sciences, Coimbra, Portugal
}

\begin{abstract}
Radon concentration measurements were performed in indoor air and in natural mineral waters in seventeen Portuguese thermal spas used for therapy, drinking and irrigation purposes. The gamma doses rates were also assessed in different workplaces of the considered thermal spas. The radon concentration was measured in water samples taken from different sampling points: boreholes, springs, inhalator chambers (ORL's) and swimming pools, and in the indoor air of different treatment rooms: ORL's, swimming pools, vapours areas and Vichy shower. Radon concentration in water ranged from 26 to $6949 \mathrm{~Bq} / \mathrm{L}$ and in the indoor air ranged from $73 \mathrm{~Bq} / \mathrm{m}_{3}$ to $3479 \mathrm{~Bq} / \mathrm{m}_{3}$. The indoor gamma dose rates ranged from $0,148 \mu \mathrm{Sv} / \mathrm{h}$ to $0,644 \mu \mathrm{Sv} / \mathrm{h}$ and the annual dose rate was estimated ranging from 0,30 to $1,29 \mathrm{mSv} / \mathrm{y}$, for 2000 working hours per year, which is far below the effective dose limit for workers $(20 \mathrm{mSv} / \mathrm{y})$. Nevertheless, the great contribution for the annual effective dose will result from radon inhalation which is not included in this estimation. The remedial action level for drinking water of $1000 \mathrm{~Bq} / \mathrm{L}$ (2001/928/ EURATOM) was exceeded in 23\% of the selected thermal spas and about $80 \%$ of the total measurements of the indoor radon concentration exceeded the previous reference level of $200 \mathrm{~Bq} / \mathrm{m}_{3}$ for new buildings and about $63 \%$ exceeded the new reference level of $300 \mathrm{~Bq} / \mathrm{m}_{3}$ as established in the Directive 2013/59/EURATOM for indoor radon concentration in workplaces. Therefore, as the recommended limits for radon concentration in water and in indoor air were exceeded, appropriate actions should be taken in order to reduce the hazard to health from radon indoors and the potential resulting occupational exposure.
\end{abstract}

Key words: radon, thermal spa, dose rate, occupational exposure

DOI: 10.21175/RadJ.2016.01.014

\section{INTRODUCTION}

Radon gas is recognized as the most significant natural source of human exposure and the leading cause of lung cancer incidence, with the exception of tobacco $[1,2,3,4,5,6]$. Thermal spas have been identified as one of the professional activities with potentially higher exposure to radon mostly due to the inhalation of radon released from thermal waters [7].

Radon concentration in groundwater varies considerably ( 1 - 10 ooo $\mathrm{Bq} / \mathrm{L}$ ) depending mostly on the uranium concentration in the surrounding rock and on the water circulation [8]. Radon's solubility in water increases with decreasing temperatures and therefore much attention has been given to thermal water sources due to the potential risk to the public health. Moreover, radon concentration levels in groundwater are generally higher than in surface water [3].

Human exposure to ${ }^{222} \mathrm{Rn}$ and its decay products in water supplies can occur in two ways: by ingestion (drinking water) or by inhalation due to the release of radon into the air when using thermal waters for health purposes [9]. The risk of radon exposure is mostly associated with high radon concentrations in confined environments, and the subsequent inhalation, increasing the risk of damaging the organ cells where radon short-life products are deposited.
Several studies have been conducted worldwide to measure the concentration of radon in the water and in the air of thermal spas in order to estimate the exposure doses both for workers and for users $[8,10$, $11,12,13,14,15]$. Recently, a study carried out in thermal spas from Ischia Island showed that the average annual effective dose to workers due to radon exposure $(3,52 \mathrm{mSv} / \mathrm{y}$; range $0,01-7,03 \mathrm{mSv} / \mathrm{y})$ was higher than the dose limit imposed by Italian legislation (3 mSv) [16].

The health effects of exposure to radon in indoor environments (indoor air), and in particular, in thermal spas, depend mainly on the concentration of inhaled radon, the ventilation rate of the place, freq uency and duration of the exposure [7, 17]. In Portugal, the monitoring of radon concentration is compulsory only in buildings constructed in granite areas, particularly in the districts of Braga, Vila Real, Porto, Guarda, Viseu and Castelo Branco, due to the geological characteristics of these regions. This obligation came into force in 2006 within the new regulations for indoor air quality imposed by the Portuguese legislation [18].

The purpose of this work was to measure the radon concentrations in indoor air and in natural mineral water as well as to evaluate the gamma doses rates in different workplaces of Portuguese thermal spas.

\footnotetext{
* The paper was presented at the Third International Conference on Radiation and Applications in Various Fields of Research (RAD 2015), Budva, Montenegro, 2015.

*** Contact: mldinis@fe.up.pt
} 


\section{METHODS}

Seventeen thermal spas participated in this study, representing about $46 \%$ of all thermal spas existing in Portugal (Fig. 1). For each studied thermal spa, the radon concentrations were measured in the natural mineral water from different sampling points: boreholes $(\mathrm{BH})$, springs (SG), inhalator chambers (ORL's) and swimming pools (SP) and in the indoor air of different rooms: ORL's, swimming pools (SP), vapours areas (VA) and Vichy shower (VS). The measurements were carried out between November 2013 and September 2014. The assessment of radon concentration included measurements in two different periods (summer and winter) in the indoor air of the selected thermal spas. Regarding the assessment of radon concentration in water a single measurement was carried out directly in the water from the borehole and in the water used in the treatment rooms. Measurements of gamma radiation doses were also assessed in some of the previous locations.

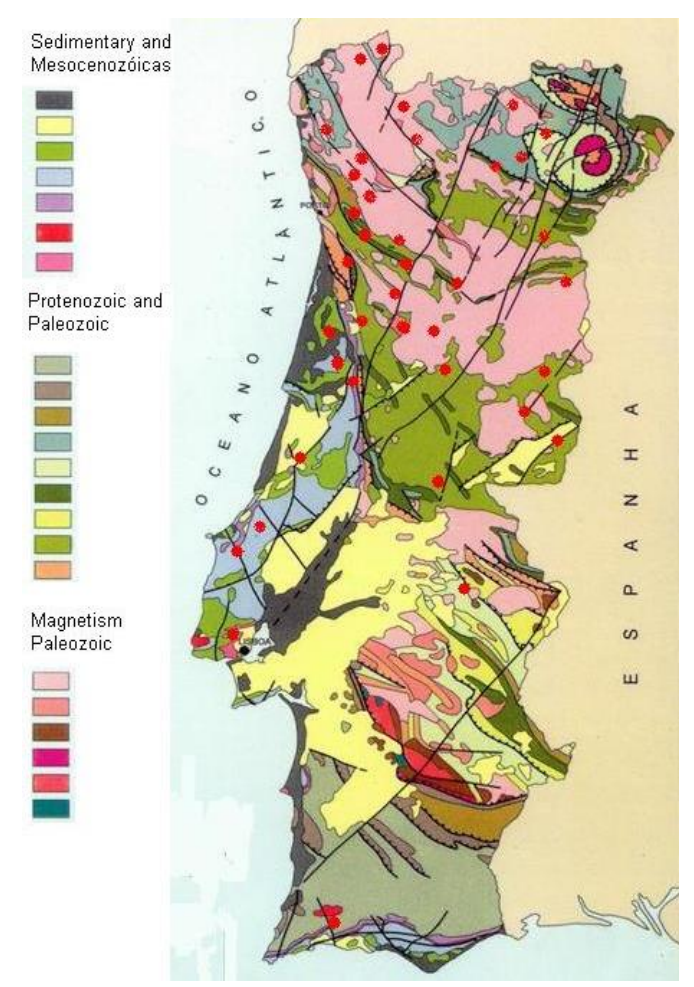

Figure 1. Location of the Portuguese thermal spas

Radon concentration in water was measured by liquid scintillation. The samples were sent to the Natural Radioactivity Laboratory of the Department of Earth Sciences, University of Coimbra, Portugal, for measurement by a liquid scintillation counter. The radionuclide activity was measured by liquid scintillation counting techniques (LSC) using an ultralow-level spectrometer (Quantulus 1220). For radon measurements the samples were collected in glass containers of $20 \mathrm{~mL}$ previously filled with $10 \mathrm{~mL}$ of a water immiscible scintillation cocktail, with sealed opening and security mechanisms to avoid gas-leakage during transport. With this protocol radon was measured through the double-phase method [19].
Radium and uranium isotopes were measured in water samples, previously filtered, acidified with $\mathrm{HNO}_{3}$ to $\mathrm{pH}$ less than 2 and, only in the former isotope, preconcentrated by evaporation. The ${ }^{226} \mathrm{Ra}$ activity was measured through the indirect method based on radon accumulation in a lipophylic scintillation cocktail during a minimum of 21 days (secular equilibrium). Before LSC counting a selective extraction of uranium was performed using an "extractive cocktail" (bis-2etilhexyl-ortophosphoric acid) and a non-water soluble scintillation cocktail. After phase separation the cocktail, collected in polyethylene vials, is measured from the peaks of ${ }^{238} \mathrm{U}$ and ${ }^{234} \mathrm{U}$. This method has been tested by comparison with other methods (like ICPMS) and the results shows good agreement [20].

The uncertainties depend on the activities but, for the range of values measured, were generally lower than $15 \%$. For a more detailed description about the LSC techniques, see [21]. Efficiency was evaluated by measuring several standard solutions and participation in intercomparison exercises.

Radon concentration measurements in air were performed using CR-39 detectors enclosed in small cylindrical (5-cm height, 3 - $\mathrm{cm}$ diameter) diffusion chambers for periods between 25 and 45 days. This detector is a small piece of plastic that is sensitive to tracks of highly ionizing particles such as alpha particles. The CR-39 detectors were placed in each room at approximately 2 meters from the floor (breathing zone) [22]. After a period of exposure between 25 and 45 days, the detectors were retrieved and sent to the Natural Radioactivity Laboratory of the Department of Earth Sciences, University of Coimbra, Portugal.

Indoor gamma dose rates were performed by a Geiger counter (Gamma Scout) which is a calibrated measurement instrument for alpha, beta and gamma rays. This device was used for the measurement of gamma doses rates which was hourly acquired and stored for a time period between 25 and 45 days. Since this system acquires the dose continuously the variation of dose during different periods of time is averaged out. Therefore, long-term integrated measurements of gamma dose may be taken.

\section{RESUlts AND DisCUSSION}

\subsection{Radon concentration in natural mineral water}

The results of radon concentration in natural mineral water samples taken from each one of the studied thermal spas (TS) are presented in Fig. 2 and Fig. 3. Radon concentrations in natural mineral water from ORL's range between $26 \mathrm{~Bq} / \mathrm{L}$ and $5325 \mathrm{~Bq} / \mathrm{L}$ (Fig. 1). About $33 \%$ of the water samples taken in ORL's from the considered thermal spas exceeded the action level for radon concentration recommended by the European Commission 2001/928/EURATOM, establishing for concentrations in excess of $1000 \mathrm{~Bq} / \mathrm{L}$, remedial action is deemed to be justified on radiological protection grounds. In what concerns to water samples taken from the ORL's of TS7, the values of radon concentration are very different: $2624 \mathrm{~Bq} / \mathrm{L}$ 
(ORL 7.1) and $1461 \mathrm{~Bq} / \mathrm{L}$ (ORL 7.2). This can be explained by the different type of treatment (water utilization) in each one of these ORL's. In addition, another important variable is that $\mathrm{TS} 7$ has an operating ventilation system which may function in two ways: first to exchange air with the outdoor and secondly, to create over-pressurised air in order to avoid the radon intrusion into the ORL's. The greater the pressure differential the higher the radon level which suggests that ORL 7.1 presents a higher pressure differential than ORL 7.2.

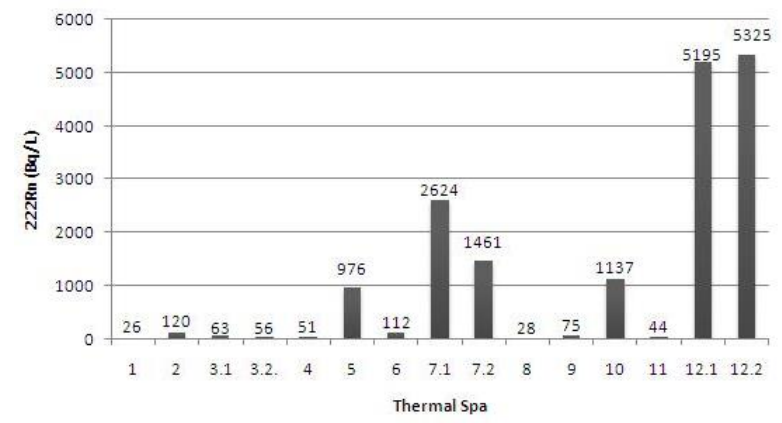

Figure 2. Radon concentration in water samples taken from the ORL's chambers $(\mathrm{Bq} / \mathrm{L})$

In what concerns to water samples taken from the boreholes (BH) (Fig. 3), the concentration of radon is higher than in the water from the ORL's, ranging between $41 \mathrm{~Bq} / \mathrm{L}(\mathrm{TS} 1)$ and $6949 \mathrm{~Bq} / \mathrm{L}$ (TS17, $\mathrm{BH} 17.1)$. However, only in $25 \%$ of the water samples, taken from boreholes of the 17 studied thermal spas, the concentrations were excess of $1000 \mathrm{~Bq} / \mathrm{L}$. The high concentrations of radon found in TS11 and TS17 may be explained by local the geological settings, a bedrock composed by metasedimentary rocks with high uranium and thorium occurrences $[13,14]$.

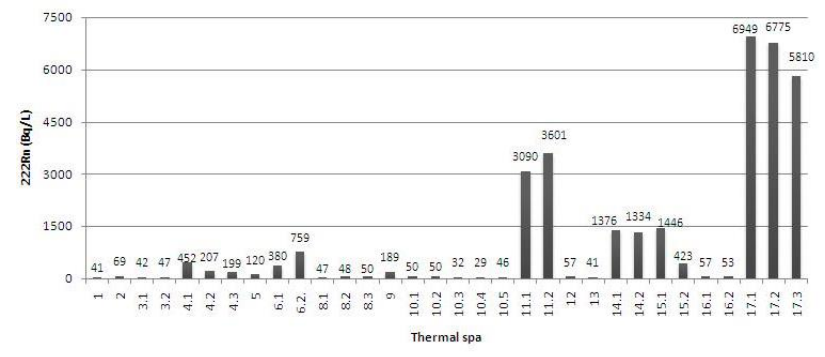

Figure 3. Radon concentration in water samples taken from the boreholes $(\mathrm{Bq} / \mathrm{L})$

The radon concentration was measured in the water from the buvettes of 2 thermal spas which may be used for ingestion depending on the medical prescriptions. The obtained results, $59 \mathrm{~Bq} / \mathrm{L}$ for TS1 and $973 \mathrm{~Bq} / \mathrm{L}$ for TS2, only the TS1 did not exceed the reference level recommended by the European Union (100 Bq/L). Nevertheless, this difference is mostly due to the geological settings and consequently different characteristics of the thermal water from each one of these thermal spa.

The concentration of radon was also analysed in water samples taken from the springs of 3 thermal spas. Only one result exceeded the reference level recommended by the European Union (100 Bq/L): 23 $\mathrm{Bq} / \mathrm{L}(\mathrm{TS} 1), 86 \mathrm{~Bq} / \mathrm{L}(\mathrm{TS} 2)$ and $478 \mathrm{~Bq} / \mathrm{L}(\mathrm{TS} 3)$.

\subsection{Radon concentration in the indoor air}

The results of radon concentration measured in the indoor air for each one of the studied thermal spas (TS) are presented in Table 1.

Table 1 Radon concentration in indoor air

\begin{tabular}{|c|c|c|}
\hline TS & Sampling location & $\begin{array}{l}{ }^{222} \mathrm{Rn} \\
\left(\mathrm{Bq} / \mathrm{m}^{3}\right)\end{array}$ \\
\hline \multirow[t]{5}{*}{1} & Technical area & 422 \\
\hline & Medical Office & 577 \\
\hline & Thermal pool & 355 \\
\hline & ORL & 707 \\
\hline & Hall Spa & 841 \\
\hline \multirow[t]{4}{*}{2} & Technical area & 481 \\
\hline & Thermal pool & 618 \\
\hline & Access corridor to the thermal pool & 1079 \\
\hline & Ludic pool & 641 \\
\hline \multirow[t]{5}{*}{3} & ORL & 375 \\
\hline & Steam hall & 398 \\
\hline & Bathtubs & 172 \\
\hline & Thermal pool & 370 \\
\hline & Sludge area & 467 \\
\hline \multirow[t]{3}{*}{4} & Rehabilitation pool & 813 \\
\hline & Thermal pool & 862 \\
\hline & Technical area & 1692 \\
\hline \multirow[t]{5}{*}{5} & Thermal pool & 517 \\
\hline & Treatment area & 692 \\
\hline & Vichy shower & 724 \\
\hline & ORL & 329 \\
\hline & Access corridor to the thermal pool & 566 \\
\hline \multirow[t]{4}{*}{6} & Thermal pool & 449 \\
\hline & ORL & 3479 \\
\hline & Vichy shower & 674 \\
\hline & Thermal pool & 784 \\
\hline \multirow[t]{5}{*}{7} & ORL & 502 \\
\hline & Thermal pool & 274 \\
\hline & ORL & 401 \\
\hline & Vapours & 453 \\
\hline & Vichy shower & 437 \\
\hline \multirow[t]{3}{*}{8} & ORL & 169 \\
\hline & Vichy shower & 406 \\
\hline & Thermal pool & 121 \\
\hline \multirow[t]{4}{*}{9} & ORL & 312 \\
\hline & Access corridor to the thermal pool & 116 \\
\hline & Vichy shower & 112 \\
\hline & Thermal pool & 73 \\
\hline \multirow[t]{5}{*}{10} & Jet shower & 1130 \\
\hline & ORL & 2298 \\
\hline & Vichy shower & 1971 \\
\hline & Technical area & 1145 \\
\hline & Thermal pool & 1494 \\
\hline \multirow[t]{3}{*}{11} & ORL & 146 \\
\hline & Thermal pool & 203 \\
\hline & Vichy shower & 93 \\
\hline \multirow[t]{2}{*}{12} & ORL & 169 \\
\hline & Vichy shower & 376 \\
\hline
\end{tabular}

The highest values of radon concentrations in indoor air were registered in the ORL's of TS6 and TS10, followed by the Vichy shower of TS10 and technical area of TS4, which are above of the reference level of $300 \mathrm{~Bq} / \mathrm{m}^{3}$, as published in the Directive 2013/59/EURATOM, laying down the basic safety 
standards for protection against the dangers arising from exposure to ionizing radiation. These thermal spas have only natural ventilation (no mechanical) and are inserted in a radon prone area (with a geological setting mainly comprised by granites) in addition to the presence of a dense network of tectonic fractures intersecting different geological units. Lower radon concentrations were recorded in the thermal swimming pool of TS9 and Vichy shower of TS11. In spite of these thermal spas being located in a geological setting favourable to the radon generation these have mechanical ventilation which may be the main reason for the lower values of radon concentration.

\subsection{Indoor gamma dose rates}

The indoor gamma dose rate was measured every hour $(\mu \mathrm{Sv} / \mathrm{h})$ in different areas of 13 thermal spas: Medical Office (MO), Technical Area (TA), ORL, Thermal Pool (TP) and Steam Area (SA).

The dose rates were registered for periods between 25 and 45 days. The basic statistic parameters are presented in Fig. 4 for average (AV), median (MD), standard deviation (SD), minimum (Min) and maximum (Max).

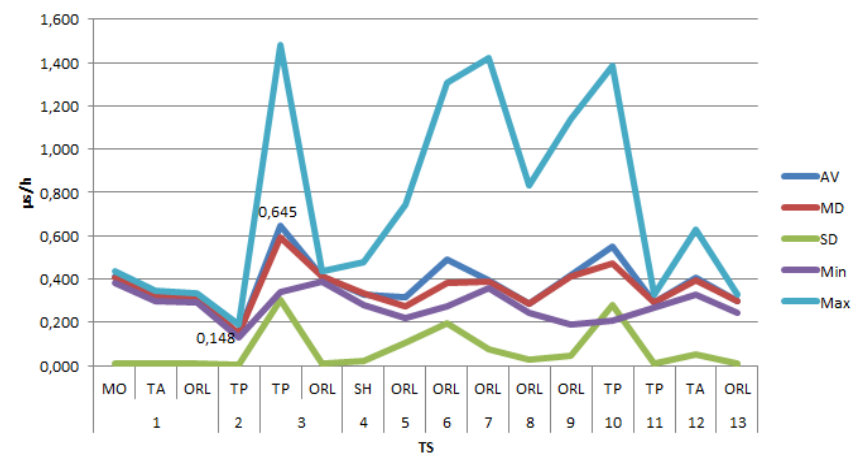

Figure 4. Indoor gamma dose rates $(\mu \mathrm{Sv} / \mathrm{h})$

The average of gamma dose rates ranged between $0,148 \mu \mathrm{Sv} / \mathrm{h}$ (TS2) and o,645 $\mu \mathrm{Sv} / \mathrm{h}$ (TS3). This reflects the very different geological settings, in particular for the thermal spa with the highest dose rate $\left(\mathrm{SP}_{3}\right)$ and for the thermal spa with the lowest dose rate (SP2), which are located in a zone comprised predominantly of granitic rock and in a geological framing comprised mostly of metasedimentary rock, respectively.

The gamma dose rates ranged between $0,15 \mu \mathrm{Sv} / \mathrm{h}$ and $0,65 \mu \mathrm{Sv} / \mathrm{h}$. The annual dose rate was estimated varying between 0,30 and $1,29 \mathrm{mSv} / \mathrm{y}$, for 2000 working hours per year, which is far below the effective dose limit for workers $(20 \mathrm{mSv} / \mathrm{y})$ (Directive 43/EURATOM). However the great contribution for the annual effective dose will result from radon inhalation which is not included in this estimation.

\section{CONCLUSIONS}

The results showed that the recommended limit for drinking water of $100 \mathrm{~Bq} / \mathrm{L}$ (2001/928/ EURATOM) was exceeded in $51 \%$ of the selected thermal spas.
About $80 \%$ of the total measurements of indoor radon concentration exceeded the previous EU reference level of $200 \mathrm{~Bq} / \mathrm{m}^{3}$ for new buildings and about $63 \%$ exceeded the new reference level of $300 \mathrm{~Bq} / \mathrm{m}^{3}$ (Directive 2013/59/EURATOM). Therefore, as the recommended limits for radon concentration in water and in indoor air were exceeded, appropriate actions should be taken in order to reduce the hazard to health from radon indoors and the potential resulting occupational exposure.

\section{REFERENCES}

1. S. Alberigi, B.R. Pecequilo, H.A. Lobo and M.P. Campos, "Assessment of Effective Doses from Radon Levels for Tour Guides at Several Galleries of Santana Cave, Southern Brazil, with CR-39 Detectors: Preliminary Results," Rad. Prot. Dos., vol. 145, no. 2-3, pp. 252-255, Mar. 2011.

2. Y. Yarar, T. Gunaydi, N. Celebi, "Determination of Radon Concentrations of the Dikili Geothermal Area in Western Turkey," Rad. Prot. Dos., vol. 118, no. 1, pp.7881, Feb. 2006.

3. M. Erdogan, F. Ozdemir and N. Eren, "Measurements of Radon Concentration Levels in Thermal Waters in the Region of Konya, Turkey," Isot. Environ. Health Stud., vol. 49, no. 4, pp. 567-574, Aug. 2013.

4. T.O. Santos, Z. Rocha, P. Cruz, V.A. Gouvea, J.B. Siqueira and A.H. Oliveira, "Radon Dose Assessment in Underground Mines," Rad. Prot. Dos., vol. 160, no. 1-3, pp. 120-123, Apr. 2014.

5. D. Nikolopoulos, E. Vogiannis, E. Petraki, A. Zisos and A. Louizi, "Investigation of the Exposure to Radon and Progeny in the Thermal Spas of Loutraki (AtticaGreece): Results from Measurements and Modelling," Sci. of the Total Environ., vol.408, iss.3, pp. 495-504, Jan. 2010.

6. T. Vaupotic, T. Streil, S. Tokonami and Z.S. Zunic, "Diurnal Variations of Radon and Thoron Activity Concentrations and Effective Doses in Dwellings in Niska Banja, Serbia," Rad. Prot. Dos., vol. 157, no. 3, pp. 375-382, 2013.

7. A.S. Silva, M. L. Dinis and A. Fiuza, "Research on Occupational Exposure to Radon in Portuguese Thermal Spas," in Occupational Safety and Hygiene II, P.M. Arezes et al., Eds., London, England: Taylor \& Francis, 2014, ch. 57, pp. $323-328$.

8. J. Nikolov et al., "Radon in Thermal Waters in SouthEast Part of Serbia," Radiation Protection Dos., vol. 160, no. 1-3, pp. 239-243, 2014.

9. A. Koray, G. Akkaya, A. Kahraman and G. Kaynak, "Measurements of Radon Concentrations in Waters and Soil Gas of Zonguldak," Rad. Prot. Dosim., vol. 162, no. 3, pp. 375-387, Nov. 2013.

10. M.A. Ziane, Z. Lounis-Mokrani and M. Allab, "Exposure to Indoor Radon and Natural Gamma Radiation in Some Workplaces at Algiers, Algeria," Rad. Prot. Dosim., vol. 160, no. 1-3, pp. 128-133, July 2014.

11. N. Kavasi et al., "Effect of Radon Measurement Methods on Dose Estimation," Rad. Prot. Dosim., vol. 145, no. 23, pp. 224-232, 2011.

12. F. Oner, I. Yigitoglu and H.A. Yalim, "Measurements of Radon Concentration in Spa Waters in Amasya, Turkey," Rad. Prot. Dosim., vol. 157, no. 2, pp. 221-224, May 2013 . 
13. K. Jile, M. Slezákova and J. Thomas, "Diurnal and Seasonal Variability of Outdoor Radon Concentration in the Area of the NRPI Prague," Rad. Prot. Dosim., vol. 160, no. 1-3, pp. 57-61, 2014.

14. M. Moldovan et al., "Radon and Radium Concentration in Water from North-West of Romania and the Estimates Doses," Rad. Prot. Dosim., vol. 162, no. 1-2, pp. 96-100, 2014.

15. G. Trabidou and H. Florou, "Estimation of doses rates to humans exposed to elevated natural radioactivity through different Pathways in the Island of Ikaria, Greece," Rad. Prot. Dosim., vol. 142, no. 2-4, pp. 378384, 2010.

16. M. Pugliese, M. Quarto and V. Roca, "Radon Concentrations in Air and Water in the Thermal Spas of Ischia Island," Indoor and Built Environ., vol. 23, no. 6, pp. 823-827, 2013.

17. S. Labidi, F. Essafi and H. Mahjoubi, "Estimation of the Radiological Risk Related to the Presence of Radon 222 in a Hydrotherapy Centre in Tunisia," J. Radiol. Prot., vol. 26, no. 3, pp. 309-316, 2006
18. A.S. Silva and M. L. Dinis, "The Presence of Radon in Thermal Spas and their Occupational Implications - a review," in Occupational Safety and Hygiene III, P. Arezes et al., Eds., London, England: Taylor \& Francis, 2015, ch. 13, pp. $59-65$.

19. Standard Test Method for Radon in Drinking Water, ASTM D5072-09e1, 2009. Retrieved from: http://www.astm.org/DATABASE.CART/HISTORICAL /D5072-09E1.htm

20. R. Rusconi et al., "The Monitoring of Tap Waters in Milan: Planning Methods and Results," Rad. Prot. Dosim., vol. 111, no. 4, pp. 373-376, 2004.

21. C.V.M. Goncalves and A.J.S.C. Pereira, "Radionuclides in Groundwater of the Serra do Bucaco Region (Central Portugal)," in Proc. of the XXXV Congr. of the Int. Assoc. of Hydrogeol., Lisbon, Portugal, 2007, pp.

22. A. Louro et al., "Human Exposure to Indoor Radon: a Survey in the Region of Guarda, Portugal," Rad. Prot. Dosim., vol. 154, no. 2, pp. 237-244, Apr. 2013. 